\title{
The role of government auditing in controlling the level of corruption in Indonesia
}

\author{
Anggreni Dian Kurniawati ${ }^{*}$, Yohanes Mario Pratama \\ Faculty of Business and Economics, Universitas Atma Jaya, Yogyakarta, Indonesia \\ ${ }^{*}$ Corresponding author email: anggreni.kurniawati@uajy.ac.id
}

\section{A R T I C LE I N F O}

Article history:

Available online

Keywords:

Irregularities, audit opinions, audit rectification, corruption, provincial government

DOI:

https://doi.org/10.20885/jaai.vol25.i ss1.art6

\section{A B S T R A C T}

The regional autonomy system has a great impact on the Indonesian local government to create good governance so as to prevent corruption. This study aims to examine the impact of detection of irregularities, audit opinion, and audit rectification on the level of corruption in provincial governments in Indonesia. The data collected in this research was the audit report of the Audit Board of the Republic of Indonesia and the annual report of The Corruption Eradication Commission in 34 provinces in 2015-2019. Further, the data was analyzed using multiple linear regression. The results indicate that the detection of irregularities and audit rectification has a positive impact on the level of corruption, while the irregularities and audit opinion do not have impact on the level of corruption. These results are expected to encourage the government to strengthen its financial supervision system.

\section{Introduction}

Regional autonomy which has been implemented by Indonesia since the enactment of Law Number 5 of 1974 concerning the Principles of Government in Regions, was further refined into Law Number 32 of 2004 which was later revised back to Law Number 23 of 2014 concerning Regional Government. Based on the principle of regional autonomy which comes from the central government to regional governments, the central government is obliged to give some rights and authority to local governments to manage their government systems independently (Sommaliagustina, 2019). This means Indonesia's local governments or provincial governments have the authority to regulate the interests of the community and make policies and regulations to manage their own regions. Indonesia's regional autonomy requires a dispersal of power. It is because when humans are in power, they have a tendency to abuse this power for an absolute power can be misused. Decentralization or the dispersion of power is believed to have a positive impact because the community will have a more active involvement in the decision-making process by the government. However, this decentralization also brings a negative side, namely the amount of corruption that occurs in the regions (Sommaliagustina, 2019). Local governments that implement regional autonomy with the freedom to regulate their own households have the possibility to abuse their power which triggers corrupt behaviour.

Corruption is a type of occupational fraud that is difficult to detect and is associated with power. This is because this action involves many parties and the evidentiary documents are very difficult to detect (Handoyo, 2016: 116-117). The results of a survey conducted by the Association of Certified Fraud Examiners (ACFE) in 2019 show that the fraud that occurs most often and causes large losses is the criminal act of corruption, which is between Rp. 100 million and Rp. 500 million per case. This case can be detected in less than 12 months due to the role of the media in detecting fraud through complaint reporting facilities or channels available to the public. Based on the profile of the perpetrators of fraud, the majority have the opportunity to manage the company or institution and have a good educational background. Moreover, based on the Corruption Perception Index ranking for 2019, Indonesia was ranked 85th out of 180 countries surveyed with a score of 40/100. The Corruption Perception Index score ranges from 0 to 100 points for a score of 0 which means that the country has a high level of corruption and for a score of 100 the country is free of corruption. The score obtained by Indonesia had increased compared to 2018, which was a two-point increase yet still below the average score obtained by ASEAN countries of 46. Indonesian Corruption Watch notes that the corruption cases investigated by the Corruption Eradication Commission, during 2019, the Attorney General's Office and Police found 271 cases of corruption with a total of 580 suspects and the amount of state losses due to corruption was IDR 8.04 trillion. Indonesian Corruption Watch also states that throughout 2019, many criminal acts of corruption occurred in Civil Servants working in local governments, there were around 263 cases that occurred, followed by village officials as many as 188 cases and finally private parties. The results of the survey and the low Corruption Perception Index score were in line with the 
findings of the Indonesian Institute of Sciences in 2007 and the United Nations Development Program in 2008 stating that the implementation of regional autonomy is very far from expectations and even shows failure.

The number of corruption cases committed by regional heads shows that regional autonomy, in this case decentralization, is the main problem in achieving a government that is free from corruption. The phenomenon of many cases of corruption has the potential to generate corrupt regulations so that local government officials have the opportunity to extract public money with the existence of regulations that they make themselves (Guntara, 2020). The strategy that can be done to fight corruption in Indonesia is by developing good governance. The aim of good governance in the public sector is to promote better service delivery and better accountability by setting benchmarks for good governance in the public sector (IFAC, 2001). According to Setyaningrum et al. (2017), good governance and quality of public services are strongly associated with low levels of corruption. The government must pay more attention to administrative and financial accountability as well as the timeliness of reporting because it is proven to reduce corruption.

The effective implementation of good corporate governance can become the government's control. Furthermore, with the power it has, it can avoid the government from power abuse such as assets misusing or criminal acts of corruption. In order to create good governance, the government has formed several units and institutions used to combat corruption, namely the Government Internal Supervisory Apparatus, the Regional Audit Board, and the Corruption Eradication Commission.

The Government Internal Supervisory Apparatus is a unit under the regional head in charge of overseeing the internal control system of ministries or local government agencies. This internal control system is an important element in a government institution because acts of corruption occur due to weak supervision systems within the scope of local government. The benefit of audit findings in the internal control system is that it can be a means of detecting fraud in criminal acts of corruption within the government, not only the central government, but also local governments. This audit is carried out by the Indonesian Supreme Audit Institution which is established by the government and has the duty and responsibility to examine the implementation process and the responsibility for the use of state funds so that they are not misused. Government institutions can use the results of Indonesian Supreme Audit Institution audits as guidelines and means of formulating strategies in an effort to minimize the occurrence of corruption cases. The results of the audit by the Indonesian Supreme Audit Institution consists of several things, including the results of audit findings regarding the internal control system, local government noncompliance with statutory provisions, and audit opinions for the implementation of regional government finances.

If there is an increase in local government non-compliance with laws and regulations, this could lead to the possibility of corruption in local government administration. The audit findings on non-compliance disclosed by the Indonesian Supreme Audit Institution prove that there have been violations of laws and regulations, including criminal acts of corruption, misuse and waste of state funds. Fraud such as corruption can be suppressed if preventive measures are taken properly by auditing the financial statements of the local government and detecting such non-compliance early.

Apart from detecting non-compliance with legislation, audit opinion is an important element in assessing the effectiveness of state financial management carried out by local governments. The level of accountability of a financial report presented is considered good if it gets a fair audit opinion, so that it is expected to reduce the level of corruption that occurs. When the local government gets a good audit opinion, this shows that the administration and management of state funds in the area has been carried out properly and is free from various forms of fraud, especially corruption. The following Figure 1.1 is a chart of the provincial government's opinion recapitulation from 2015-2019 for the unqualified (WTP) and non-unqualified (non-WTP) categories.

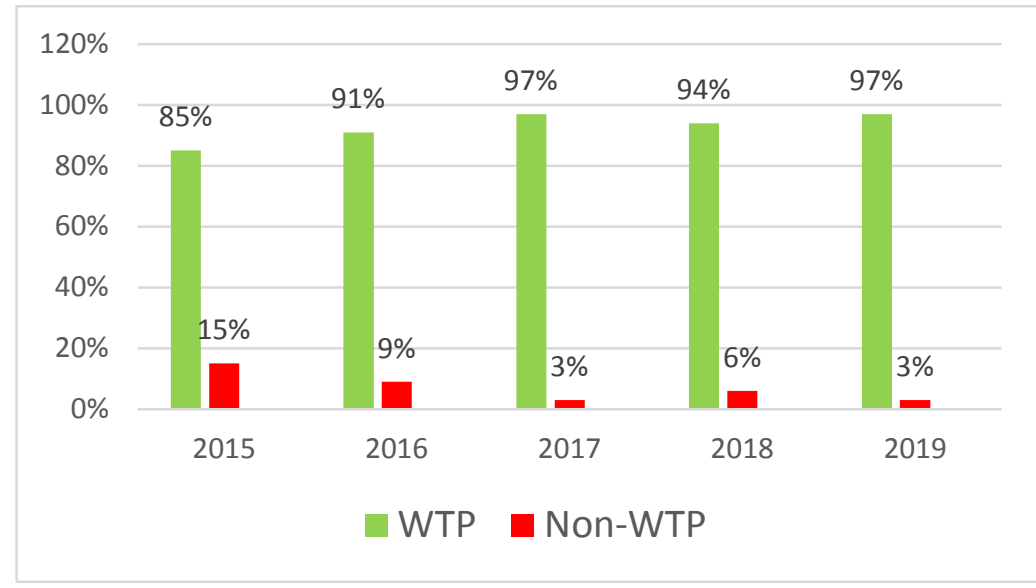

Figure 1. Recapitulation Provincial Government Opinion for the period of 2015-2019 based on Audit Report Result by The Audit Board of Republic Indonesia 
Based on this chart, it can be seen that the level of the accountability of the provincial government financial report always increases with the number of unqualified opinions. In fact, an audit opinion and a good financial performance do not necessarily guarantee that the provincial government is free from corruption cases. Moreover, unqualified opinion does not necessarily guarantee that the institution is free from criminal acts of corruption. In 2018, The Audit Board of Republic Indonesia was reported that the Governor of Jambi Province was arrested for being caught in a corruption case for ratifying the 2018 Regional Budget Plan. This fact is inversely proportional to the unqualified audit opinion obtained by Jambi Province in 2017 and 2018.

In its financial audits, the Indonesian Supreme Audit Institution also provides several recommendations to local governments to improve the quality of their financial management processes so that corruption can be avoided. Follow-up recommendations given by the examiner to the local government is an important stage and must be carried out by the local government after the inspection process. The follow-up in the form of corrections after the examination process is the best way that can be done by local governments. The corrections are done as a form of accountability for the use of state funds and mistakes made in the administration of their government. As a result, the quality of a region will increase in line with the number of investigators' recommendations which are followed up by the regional government.

The phenomenon of increasing cases of corruption which has happened since the existence of this regional autonomy system is the background for the author to prove empirically that irregularities, audit opinions, and audit rectification results are factors that influence the existence of corruption in local governments. The results of this study are expected to contribute to the efforts to eradicate corruption in local governments and provide recommendations to local governments on the governance in order to create an anti-corruption culture.

\section{Literature Review}

In general, corruption is defined as a behaviour that deliberately misuses one's position in the government sector to gain individual benefits. This definition can include the activities of buying and selling state assets that are carried out illegally, procurement through kickbacks, gratuities, or embezzlement of various government funds. In the sociological approach, the commonly used definition of corruption is "abuse of official authority for personal gain" (Tuanakotta, 2010). The conflict of interest that occurs between the community and local government is one of the reasons for the emergence of opportunities for this corruption act. This can be described in the framework of agency theory with the community as the principal party and the local government as the agent. Local governments use state funds in the form of the Regional Development and Expenditure Budget and the public demands transparency and accountability for these budgets. Engaging citizens to actively participate in the anti-corruption movement may increase the chance of success in eradicating corruption in the future (Prabowo et al., 2018).

Misuse of state funds may occur due to information gaps between local governments and the community. This is because the information related to regional budgets is mostly owned by local governments as regional managers rather than the community. This information gap can also lead to fraud because the local government, which should carry out the mandate of the community to make the best use of financial funds, sometimes neglect professionalism and prioritize personal welfare by abusing the authority entrusted by the community to lead an area. Efforts that can be made to reduce the agency problem can be done by monitoring the performance of local governments and ensuring that laws and regulations have been implemented in the process of managing state funds. Examples of forms of supervision that can be done are auditing financial reports and government performance. Furthermore, increasing accountability for local government performance can be done to reduce the level of information gaps. The reduced level of information gaps is expected to reduce the level of corruption that occurs. The output form of the Indonesian Supreme Audit Institutions' examination results is the opinion and the audit findings reported in the Audit Result Report (LHP). Based on the Decree of Indonesian Supreme Audit Institution No. 5/K/I-XIII.2/8/2010 dated 27 August 2020 containing Technical Guidelines for Inspection Findings Codering, there are several findings, namely the findings of the Internal Control System, Non-compliance with legislation, and 3E (Economical, Efficient, and Effective).

Weak internal government control systems can lead to the vulnerability of a government towards corruption. Based on the Regulation of the Minister of Home Affairs Number 4 of 2008 concerning Guidelines for Implementing Reviews of Regional Government Financial Reports and Government Regulation of the Republic of Indonesia Number 60 of 2008 regarding the Internal Control System, the internal control system is a structured method that is carried out on an ongoing basis by leaders and employees. Moreover, it is influenced by management to achieve the objectives of effectiveness and efficiency of activities, reliability in the presentation of financial reports, protected state assets, and implementation of laws and regulations in the process of managing state funds to achieve institutional goals.

The applicable laws and regulations must be implemented by the government in the implementation of the internal control system, accounting and financial reporting. In the State Financial Audit Standards, one of the 
important components that must be disclosed in assessing the accountability of a financial report is compliance the laws and regulations. Financial reports that are presented by the regional government must obtain an official statement from the examiner that the financial statements do not contain material misstatements due to noncompliance with the provisions of the laws and regulations carried out by the local government. The examination process for non-compliance with statutory provisions is stated in the form of an Audit Result Report.

Masyitoh et al. (2015) reveals that there is a strong influence of audit findings on non-compliance with laws and regulations on perceptions of corruption in local government. This non-compliance finding indicate that local governments have violated or disobeyed laws and regulations, so the potential for irregularities is higher. In addition, violations of laws and regulations can cause material losses in regional finances, resulting losses in the future. Increasing compliance with laws and regulations is a way to prevent the possibility of accounting fraud in an organization because it can help organization provide information on corporate financial statements objectively to interested parties. This is because compliance with laws and regulations can form high management morality and can reduce the tendency of accounting fraud committed by management (Sari and Prabowo, 2019). Poor governance processes in a region that trigger corruption can be indicated by cases of violations or non-compliance of the local government with statutory provisions. Atmaja and Probohudono (2015) state that the findings on noncompliance with legislation indicate that local governments are still unable to carry out a system of governance and organizational activities effectively and efficiently. Other than that, the findings of non-compliance with legislation indicate that local or provincial governments are still unable to optimize the processes of managing, controlling and presenting financial statements. As a result, the allocation of funds for the interests of the community have not been properly absorbed and are not well targeted.

Apart from non-compliance with applicable laws and regulations, audit opinion can also be an important information to increase public confidence in local government financial governance processes and systems. Law Number 15 of 2004 concerning the Management and Accountability Audit of State Finances Article 1 Paragraph 11 explains that the conclusions made by the examiner in a professional manner is to determine the information in the financial statements presented is reasonable as an audit opinion. The audit opinion is a professional statement by the examiner as a conclusion as to whether the information presented in the financial statements is fair or not, so that the source of the information contained therein can be trusted as a basis for decision making.

Masyitoh et al., (2015) believes that the audit opinion obtained can reflect the fairness level of the information presented in the financial statements and show how the government is performing in the process of governance in the regions; if the audit opinion obtained by a government is good, then the local government has performed well so that there is no potential for misappropriation of state funds. Audit opinion on fair financial statements is information that illustrates that the provincial and local governments have carried out a good accountability process which is believed to be able to contribute to reducing the level of corruption. A qualified audit comes from an independent process and the high professionalism conducted by the expert auditor (Hamdani et al., 2020). Based on the previous research by Jehandu et al. (2019) in Papua Province government, when the perception of the audit opinion is good, confidence in the handling of corruption by the auditor will be higher. The objective of conducting an audit of financial statements is to evaluate whether the presentation of financial information in the financial statements has been presented fairly or not. At the end of the examination, the auditor evaluates the findings as a whole compared to the applicable standards to provide an opinion whether the financial statements have been fairly presented or not. The auditor's opinion becomes the basis for an assessment of the level of fairness which provides an overview of the level of accountability of the provincial government as a form of contribution in reducing the level of corruption. If the fairness of the financial statements is good, it can be believed that a good accountability process has been implemented to reduce corruption, and vice versa.

Based on Law Number 15 of 2004 concerning Audit, Management and Accountability of State Finances, the recommendation is a means to take corrective actions given by the examiner to an individual or to an authorized board on the results of the audit that has been carried out. The follow-up recommendations on the results of the audit are actions that must be carried out by the person or board being examined to implement the recommendations from the financial examiner.

According to Liu and Lin (2012), it is more important to carry out follow-up activities on results than to detect audit findings because it can increase the effectiveness of the audit process. A party that has implemented the recommendations given by the examiner can eliminate and even prevent the same mistakes from being repeated, such as misappropriation and waste of state funds. Local governments that have implemented recommendations from the examiners show that the regional governments have made efforts to correct mistakes and forms of accountability in the process of governance. Azhar and Setyaningrum (2015) suggest that the better the follow-up improvements made, the lower the level of corruption. It is because by following up the results of the audits given by the auditors, Ministries or institutions have made efforts to improve the internal control system so that it can detect fraud or corruption that occurs. Umar (2012) states that the existence of an audit examination is expected to be a recommendation for decision makers to stop or eliminate and prevent the recurrence of mistakes, 
irregularities, fraud, waste, obstacles, and injustice. In addition, the audit results are expected to provide better ways to achieve organizational goals and achieve the vision and mission.

Good state financial governance will be able to be constructed if the process of examining the management and accountability of state funds is prepared in accordance with appropriate principles and legislation. The regulation regarding government audits or also known as state financial audits is stated in Law Number 15 of 2004 concerning Audit of the Management and Accountability of State Finances. In the context of government auditing, the object of the audit process is the government itself. The implementation of government activities in managing public funds, both state revenues and expenditures, can be controlled through government audits which also serve as an accountability function for the management of public funds. The use of public funds for government activities must not experience waste or even abuse but their use must be in accordance with the objectives set by the government and right on target for the benefit of the community. Government audits can be a detecting tool in the event of misuse of state funds. In addition, suggestions and recommendations can be given to improve the government accounting system upon the results of the audits that have been carried out. The authority to audit the government in Indonesia is conducted by an independent state institution which is free from executive, legislative and judicial elements as written in the laws and regulations.

In the State Financial Audit Standards, the compliance with the laws and regulations can be used to assess the accountability of a financial report by a financial auditor. The financial statements that are presented must receive an official statement from an examiner stating that the financial statements do not contain material misstatements resulting from non-compliance with the provisions of laws and regulations. Regarding this, Masyitoh et al. (2015) states that corruption occurs due to non-compliance of local governments with statutory provisions can cause state losses. Violation of laws and regulations indicate that governance in the area is poor and has the potential for fraud. If in the results of the examination it is found that there are many non-compliances with legislation, this indicates a high level of corruption. Further, Azhar and Setyaningrum (2015) state that the level of corruption in a ministry or institution can be determined by the number of audit findings reported by the Indonesian Supreme Audit Institution. When they find many findings, it can be said that the level of corruption in a ministry or institution is high. Additional testing is performed regarding internal control weaknesses. The strength or weakness of the internal control system has an impact on the level of corruption. If weak internal controls are found, the potential for fraud and corruption is even higher. The hypothesis in this study is stated as follows:

$\mathrm{H}_{1}$ : Detection of irregularities have a positive effect on the level of potential for corruption

Law Number 15 Year 2004 regarding State Financial Management and Responsibility Audit Article 1 Paragraph 11 explains that the conclusions made by the examiner in a professional manner is to determine the information in the financial statements presented is reasonable as an audit opinion. An audit opinion is a professional statement by the examiner as a conclusion as to whether the information presented in the financial statements is fair or not. Thus, the sources of information contained can be trusted as a basis for decision making. Audit opinions issued by the Supreme Audit Agency may reflect governance processes, so that the audit opinion can influence public confidence about the process of local government administration, especially in terms of accountability and transparency. Audit opinion shows the level of fairness and accountability of a financial report that can contribute to reducing the potential for corruption. Good government performance and free from potential deviations can be indicated by the existence of a good audit opinion on the financial statements. Masyitoh et al., (2015) states that audit opinion has a negative impact on the level of corruption in provincial government. The better the audit opinion obtained by the regional government, the less likely it is that corruption cases will occur. Based on research conducted by Rini and Sarah (2014), the audit opinion issued by the Indonesian Supreme Audit Institution has a relationship with the level of corruption. There were $97 \%$ districts (68\% fair with exceptions, $26 \%$ did not express an opinion, and 3\% not fair) with opinions other than fair without exception having cases of corruption. Districts that received unqualified opinion in 2011 had a corruption case rate of only $3.2 \%$. Based on this, it can be concluded that an unqualified opinion indicates that the provincial or regional government is free from corruption. The hypothesis in this study is stated as follows:

$\mathrm{H}_{2}$ : Audit opinion has an effect on the level of potential for corruption

Based on Law Number 15 Year 2004 regarding the Audit of State Financial Management and Responsibility, the recommendation is a means to take corrective actions given by the examiner to an individual or authorized board upon the results of the audit that has been carried out. Follow-up recommendations on the results of the examination are actions that must be carried out by the person or board being examined to implement the recommendations from the Indonesian Supreme Audit Institution. The local government making corrections after the audit process according to the recommendation of the examiner is a form of responsibility for any errors that occur, especially misuse of state funds so that it will have an impact on reducing the level of corruption. Rini and Damiati (2017) state that the follow-up on the results of the examination has a negative impact on the level of corruption. If the provincial and local governments carry out a follow-up process on the audit results by 
implementing the recommendations, the level of corruption in that government will be lower. Further, the previous statement is also in line with Azhar and Setyaningrum (2015) suggesting that the follow-up on the results of the examination has a negative impact on the level of corruption because the implementation of amendments to the follow-up on the results of a good examination has an impact on the lower levels of corruption. This happens because by implementing the recommendations given by auditors, ministries or institutions have shown efforts in developing their internal control systems so that they can detect fraud and corruption effectively. The hypothesis in this study is stated as follows:

$\mathrm{H}_{3}$ : Audit rectification has a negative effect on the level of potential for corruption

\section{Research Method}

This study employed a quantitative approach. The study population consisted of 34 provincial governments in Indonesia. The data was collected through indirect observation by accessing the data on the Corruption Eradication Commission Annual Report issued by the Corruption Eradication Commission's Public Complaints Division regarding indications of corruption based on recapitulation of public complaints accessed from the Corruption Eradication Commission website. In addition, researchers also collected the data on non-compliance with legislation, audit opinions, and follow-up on audit results and Audit Result Reports accessed in the Indonesian Audit Board's website. The two reports taken were the reports in the period of 2015-2019. The research sample was selected using purposive sampling method.

The dependent variable of this study was corruption. Corruption is an unlawful act intended by the perpetrators to enrich themselves, others or their groups. This corruption has an impact on the country's economy, in which it can cause losses to the country. The process of counting corruption cases is calculated by the number of corruption cases per 10,000 people. The measurement of the dependent variable referred to previous research from Liu and Lin (2012) and Rini and Damiati (2017) that has been modified to adjust the data of corruption cases in Indonesia. The indicator used is the number of corruption cases involving public complaints in each province in Indonesia that were disclosed by the KPK.

The independent variables of this study were non-compliance with statutory provisions, audit opinion, and follow-up on audit results. Measurements for the three dependent variables referred to previous research from Liu and Lin (2012) and Rini and Damiati (2017) as follows:

\section{Detection of Irregularities}

In the State Audit Standards, irregularities are the important elements for assessing the accountability of a financial report by an auditor by the Indonesian Supreme Audit Institution. In its examination, they must ensure that the laws and regulations are applied in the process of administering the provincial government, so it is necessary to disclose audit findings regarding non-compliance with statutory provisions. Natural logarithms were used to measure the number of audit findings on non-compliance with statutory provisions adjusted for population size (findings per capita).

\section{Audit Opinion}

Professional conclusions regarding the reasonableness that the information in the financial statements presented by the provincial government is included in the audit opinion. This audit opinion is needed to provide adequate confidence to the public and decision makers. This audit opinion variable was measured using a dummy variable by giving a score of 1 if the opinion was unqualified and 0 if the opinion was a qualified opinion, unfair, and disclaimer.

\section{Audit Rectification}

The audit rectification is an action that must be taken by the person or body being examined to implement a recommendation from the Indonesian Supreme Audit Institution to the person or agency authorized for the results of the audit that has been carried out. This variable was measured by carrying out the natural logarithm of the amount of the value of delivery or payment to the state or regional treasury adjusted to the total population (rupiah per capita).

Control variables are variables controlled by researchers to neutralize the influence that can strengthen the relationship between the dependent variable and the independent variable and cannot be influenced by external factors. The control variable used in this study was government size. Based on Liu and Lin (2012) and Li and Wu (2010), a larger size of government has a lower level of corruption. This is because a lot of supervision from both institutions and the public on financial accountability reduces the opportunities for personnel in the local government to commit criminal acts of corruption. The size of government was measured by dividing the consumption of a province divided by the Gross Domestic Product of the province. The result was expressed in a percentage.

The data collection technique used in this research is documentation by collecting and studying the data on the number of corruption cases obtained from the annual report of the KPK. Total data on audit findings regarding weaknesses in the internal control system and non-compliance with statutory provisions, audit opinions 
and follow-up on audit results are obtained from the official website of the Audit Board of the Republic Indonesia and contained in the Summary of Semester Audit Results (IHPS). Hypothesis testing is carried out using multiple linear regression by first performing the classical assumption test and normality test. This study used multiple regression analysis stated in the following equation:

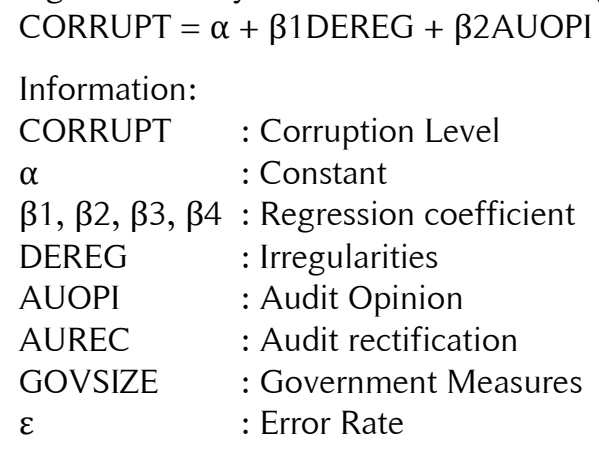

\section{Results and Discussion}

Table 1 shows the summary of the results of descriptive statistics for the dependent variable, independent variable, and control variable for this study.

Table 1. Descriptive Statistics

\begin{tabular}{lcccc}
\hline \multicolumn{1}{c}{ Variables } & Mean & Standard Deviation & Minimum & Maximum \\
\hline CORRUPT & 0.0167 & 0.0190 & 0.0009 & 0.0928 \\
DEREG & 0.0003 & 0.0001 & 0.0000 & 0.0005 \\
AUOPI & 0.9294 & 0.2568 & 0.0000 & 1.0000 \\
AUREC & 0.0022 & 0.0003 & 0.0000 & 0.0028 \\
GOVSIZE & 0.0343 & 0.0197 & 0.0065 & 0.1032 \\
\hline
\end{tabular}

Source: The result of SPSS data processing, 2021

The control variables used in this study were tested first to determine whether this control variable was able to strengthen the relationship between the dependent and independent variables. Table 2 shows the result of the partial correlation test for the government size control variable.

Table 2. Partial Correlation Test

\begin{tabular}{lcccc}
\hline \multicolumn{1}{c}{ GOVSIZE } & CORRUPT & DEREG & AUOPI & AUREC \\
\hline Correlation & -0.412 & -0.171 & -0.121 & $-0,215$ \\
Significance (2-tailed) & 0.000 & 0.027 & 0.016 & 0.005 \\
$\mathrm{~F}$ & 34.385 & & & \\
Sig. & 0.0000 & & & \\
$\mathrm{t}$ & -17.179 & & & \\
Sig. & 0.0000 & & & \\
\hline Source: The result of SPSS data processing, 2021 & & &
\end{tabular}

Source: The result of SPSS data processing, 2021

Table 3. Multiple Regression Test

\begin{tabular}{lccc}
\hline \multicolumn{1}{c}{ Variables } & Beta & $\mathrm{t}$ & Sig. \\
\hline (Constant) & 24.914 & 4.756 & 0.000 \\
AUOPI & 0.247 & 3.127 & 0.002 \\
DEREG & 0.033 & 0.552 & 0.582 \\
AUREC & 0.284 & 3.594 & 0.000 \\
GOVSIZE & -0.335 & -5.381 & 0.000 \\
\hline
\end{tabular}

Dependent Variable: CORRUPT, significance at level 5\%

Source: The result of SPSS data processing, 2021

Prior to testing the hypothesis, the researcher conducted a data normality test and a classical assumption test. Based on the Kolmogorov-Smirnov normality test, the Asymp. Sig. (2-tailed) shows a value of 0.200 and greater than 0.05 , which means that the data in this study are normally distributed. The results of the multicollinearity test state that all regression models in this study do not experience multicollinearity problems because the tolerance value for all variables is greater than 0.10 and the VIF value is less than 10. Based on the results of the heteroscedasticity test using the Park test, the significance value for all variables shows an added 
value, greater than 0.05 or alpha value, which means that the results of the test on the regression model do not occur heteroscedasticity problems. While the results of the autocorrelation test using the Durbin-Watson test show that the DW value lies between the $\mathrm{dU}$ value and $(4-\mathrm{dU})$ or $(1.743<0.881<2.257)$. It can be concluded that there is no autocorrelation. The table of classical assumption test results can be seen in the appendix. The results of the multiple regression test are shown in Table 3.

The research regression model is stated in the following equation:

CORRUPT $=24.914+0.247$ DEREG + 0.033AUOPI + 0.284AUREC -0.335 GOVSIZE $+\varepsilon$

Table 3 shows that the variable irregularities (DEREG) have a t value of 3.127 and a significance of 0.002 , smaller than the alpha value of 0.05 . Therefore, the conclusion is that detection of irregularities has a positive effect on the level of corruption, which means $\mathrm{H} 1$ is accepted. The audit opinion variable (AUOPI) has a t value of 0.552 and a significance of 0.582 , greater than the alpha value of 0.05 . The conclusion is that the audit opinion variable does not have an effect on the level of corruption, which means $\mathrm{H} 2$ is not accepted. Meanwhile, for the results of the audit rectification variable test (AUREC), it shows a t value of 3,594 and a significance of 0,000, smaller than the alpha value of 0.05 . Therefore, the conclusion is that audit rectification has a positive effect on the level of corruption, which means that $\mathrm{H} 3$ is not accepted. In addition, the control variable was used, namely the government size. The statistical results show that the $t$ value of the government size variable (GOVSIZE) is $-5,381$ with a significance of 0.000 smaller than the alpha value of 0.05 . Hence, the conclusion is that government size has a negative effect on the level of corruption.

Furthermore, the researcher also tested the goodness of fit using the $F$ test, with a significance value of 0.000 and less than an alpha value of 0.05 , which means that this research model was declared fit to be the research model. The coefficient of determination test was also carried out to see the strength of the independent variables used to explain the impact on the dependent variable. The results show that the Adjusted R-Square value is 0.413 or it can be interpreted that $41.3 \%$ of the dependent variable is influenced by the independent variable, while the remaining $58.7 \%$ is explained by other variables that are outside the research model.

The results of the first hypothesis test indicate that detection of irregularities has a positive effect on the level of corruption. The results of this study are supported by previous research from Liu and Lin (2012). Based on Indonesian Supreme Audit Institution Regulation Number 01 of 2007 concerning Financial Audit Standards, the scope of the audit by the Supreme Audit Agency includes audits of state finances, performance audits and audits for specific purposes. Types of audits included in the scope of performance audits, namely inspection of compliance with statutory provisions and examination of the internal control system. Performance examination is an examination of the management of state finances which consists of examining economic and efficiency aspects as well as examining economic aspects.

In fact, sometimes, the audit findings communicated and reported by the examiner to the provincial government for improvement efforts are not responded by the provincial government as the remedial efforts. As a result, the more repairs which are not fulfilled, the more the internal control system is weakened in preventing the misuse of funds that leads to criminal acts of corruption. Diversion of funds by a government board or government officials can result in state financial losses (Rampeengan, 2013). Thus, it can be concluded that the more detection of irregularities was found, the higher the potential for corruption in the provincial government may occur. The criminal act of corruption can become more chronic if the reporting and disclosure on bad fund management is not responded by the existence of sanctions or penalties which have a strong deterrent effect. Therefore, improving performance is an absolute necessity for the provincial government to do. Provincial governments in Indonesia must improve their internal supervision and control so that audit findings related to non-compliance with legislation and weaknesses in the internal control system can be reduced so as to prevent corruption.

The results of the second hypothesis test indicate that the audit opinion does not have effect on the level of corruption. These results have the same research as Heriningsih (2015) and Masyitoh et al., (2015). The audit opinion obtained cannot guarantee that a board is free from criminal acts of corruption because examination of financial statements is not specifically aimed at detecting corruption. If during the examination it is found that there is process of procuring goods and services deviating from the provisions, yet in terms of financial reporting it has been reported in accordance with the Government Accounting Standards, the financial report can still obtain an unqualified opinion. In fact, there are still some provincial governments whose audit opinions are unqualified, but the level of corruption is still high.

Based on the Law of the Republic of Indonesia Number 15 of 2004 Article 16 paragraph 1, an opinion is an examiner's professional statement regarding the fairness or failure of the financial information presented in the financial statements based on the criteria of conformity with the government accounting standards, adequacy of disclosure, compliance with statutory regulations, and the effectiveness of the internal control system. Unqualified opinion is the highest form of appreciation given by the auditor in assessing the management of financial statements. The provincial government receiving this opinion is believed by the examiner that based on the audit evidence collected, the financial statements are free from material errors (Rampeengan, 2013). Therefore, 
unqualified opinion is not a guarantee that an entity (provincial or local government) is free from corruption because it only assesses from its financial reporting aspect. The audit opinion issued by the Indonesian Supreme Audit Institution is assessed on the basis of whether or not the financial governance system is implemented by the provincial government. In addition, the examiner also ensures that the financial statements presented are free from material misstatement and that the presentation of the financial statements is fair in accordance with Government Accounting Standards. This audit opinion can be useful as a basis for reducing financial abuse and detecting the presence of symptoms of corruption. However, it is not the only factor.

The results of the third hypothesis test indicate that the audit rectification has a positive effect on the level of corruption. This is not in line with the results of research by Liu and Lin (2012) and Masyitoh et al. (2015). Improvement after the audit process is important to carry out because it is a form of responsibility of the provincial government for several mistakes made in the process of managing state finances. The audit findings will be useless when the provincial and local governments do not carry out the process of completing the follow-up on the audit results. It is because it cannot accomplish the goal of achieving accountability. The results of recommendations from the examiner if followed up, this can increase the effectiveness and accountability of the government audit process and prevent recurrence of mistakes and reduce the level of fraud. However, sometimes, the provincial government cannot immediately correct these mistakes. As a result, the audit findings may accumulate in the following year's examination and become increasingly material if they are not making any follow-up. Pongoliu et al. (2017) suggest that there are several obstacles in resolving the follow-up on the examination results faced by Regional Work Units. First, there is no full commitment from the officials or the State Civil Apparatus to carry out the follow-up process on the Indonesian Supreme Audit Institution audit results so they are not immediately resolved. Second, there is a repeated error because the Internal Supervisory Unit team has not carried out an optimal control and supervision process so that the internal control system in the Regional Work Units is still weak. Third, the parties related to the findings have been transferred, retired, or died so that they cannot be traced back. Fourth, Regional Work Units has not carried out the process of fully recovering state losses. Fifth, the process of completing the follow-up on the Indonesian Supreme Audit Institution audit results is not carried out quickly because there is an employee rotation system in the provincial government. Sixth, the audit findings may not be followed up for a long time because there is a disagreement over the audit results and the process for deleting the findings by Indonesian Supreme Audit Institution also has to go through a long process.

In the process of following up on the results of the examination, the provincial government may face several obstacles. These constraints include the lack of quantity and quality of human resources in the provincial government on how to follow up on the recommendations of the audit results. Moreover, the follow-up process has not been fully carried out based on the Standard Operational Procedure for the follow-up procedures for the audit results of the Indonesian Supreme Audit Institution and there is a lack of a monitoring system for the evaluation and monitoring process routine in the follow-up examinations. These are the things that still cause corruption to occur even though the follow-up results of the investigation have been carried out. Therefore, the provincial government is expected to give special attention, especially to the internal control component in the provincial government. It should be done in order to prevent corruption and optimize improvements in its financial governance system so that it can be more accountable.

Furthermore, the results of this statistical test also prove that the size of government as a control variable is able to influence a strong relationship in the non-compliance variable with statutory regulations, audit opinion, and examination findings on the variable level of corruption. The size of government is shown to have a negative effect on the level of corruption. This results supported by the research of Liu and Lin (2012) and Rini and Damiati (2017) that found that the greater the size of the government, the lower the level of corruption. The bigger the size of the government, the more people will supervise the management of regional funds. They will tend to protest if there is misuse of funds by government officials. This results in low levels of corruption.

\section{Conclusion}

Based on the discussion that has been conducted, it can be concluded that detection of irregularities and audit rectification have a positive effect on the level of corruption. Meanwhile, the audit opinion does not have any effect on the level of corruption.

This study also proves that the size of the government as a control variable is able to influence a strong relationship to detection of irregularities, audit opinion, and audit rectification on the variable level of corruption. This research is expected to be a recommendation for the Indonesian Supreme Audit Institution to communicate to provincial government officials to make improvements in financial management so that performance and accountability can increase and also have an impact on increasing public trust. The Indonesian Supreme Audit Institution can also provide an enforcement that must be given to the provincial government to do the follow up on their findings and use the findings as a basis for making improvements so that the supervision process and internal control system of each provincial government can be improved. In addition, in an effort to improve, the 
future research should be able to evaluate and increase supervision related to the process of resolving the followup on audit results because the level of corruption in the provincial government is still quite high and provide an incentive for the provincial government to follow up the Indonesian Supreme Audit Institution's findings and make these findings a basis for improving the supervision process and the internal control system.

This study has several limitations. First, the main focus of this research is still limited to the provincial government and has not expanded the scope of research to district or city governments, so the results are not generally applicable. Second, the role of the examiner in the process of detecting suspected corruption in the provincial government is only analyzed from the detection of audit findings, the provision of audit opinions and the role of the examiner in monitoring the follow-up on audit results carried out by the provincial government. There are several factors thought to be other predictors outside of this research that can be used, such as audit quality or weaknesses in the internal control system.

Future studies are expected to use a wider sample and add a longer observation year in order to obtain research results that better describe the situation in Indonesia. In addition, further research may consider the use of other control variables to strengthen the relationship between the independent and dependent variables so as to minimize the result bias.

\section{References}

Atmaja, R. S. A., \& Probohudono, A. N. (2015). Analisis audit BPK RI terkait kelemahan SPI, temuan ketidakpatuhan dan kerugian negara. Jurnal Anti Korupsi, 1(1), 81-110.

Azhar, K., \& Setyaningrum, D. (2015). Pengaruh temuan dan tindak lanjut hasil pemeriksaan BPK terhadap korupsi kementerian. Library Universitas Indonesia, 4(3), 114-130.

Guntara, B. (2020). Maraknya korupsi di pemerintahan daerah dalam era desentralisasi. Yuriskal: Jurnal IImiah Hukum, 12(1), 11-24. https://doi.org/10.24903/yrs.v12i1.813

Hamdani, R., Rahimah, I., \& Hafiz, M. S. (2020). Exploring the professionalism and dysfunctional behavior of public accountants on audit quality. Review of Integrative Business and Economics Research, 93), 9-19.

Handoyo, S. (2016). Pengantar Akuntansi Forensik dan Investigasi. Ekonesia.

Heriningsih, S. (2015). Analisis kinerja penyelenggara peFhamerintah daerah dan tingkat korupsi dianalisis dari opini auditor. Semantic Scholar, 86-95.

IFAC. (2001). Governance in the Public Sector: A Governing Body Perspective. https://www.ifac.org/system/files/publications/files/study-13-governance-in-th.pdf

Jehandu, V., Salle, A., \& Layuk, P. K. A. (2019). Pengaruh opini audit dan temuan audit terhadap tingkat korupsi di pemerintah provinsi Papua. Jurnal Kajian Ekonomi Dan Keuangan Daerah, 4(3), 114-131.

Li, S., \& Wu, J. J. (2010). Why some countries thrive despite corruption: The role of trust in the corruption efficiency relationship Why some countries thrive despite corruption: The role of trust in the corruption efficiency relation. Review of International Political Economy, 17(1), 129-154. https://doi.org/https://doi.org/10.1080/09692290802577446

Liu, J., \& Lin, B. (2012). Government auditing and corruption control $\square$ : Evidence from China 's provincial panel data. China Journal of Accounting Research, 5(2), 163-186. https://doi.org/10.1016/j.cjar.2012.01.002

Masyitoh, R. D., Wardhani, R., Setyaningrum, D., Pascasarjana, P., \& Akuntansi, I. (2015). Pengaruh Opini Audit , Temuan Audit, dan Tindak Lanjut Hasil Audit terhadap Persepsi Korupsi pada Pemerintah Daerah Tingkat II Tahun. Simposium Nasional Akuntansi XVII.

Pongoliu, R. R., Saerang, D., \& Manossoh, H. (2017). Analisis kendala penyelesaian tindak lanjut hasil pemeriksaan BPK pada pemerintah provinsi Gorontalo. Jurnal Riset Akuntansi Dan Auditing "Goodwill," 8(1), 1-10.

Prabowo, H. Y., Hamdani, R., \& Sanusi, Z. M. (2018). The new face of people power: An exploratory study on the potential of social media for combating corruption in Indonesia. Australasian Accounting, Business and Finance Journal, 12(3), 19-40.

Rampeengan, M. C. (2013). Fungsi laporan hasil pemeriksaan (LHP) Badan Pemeriksa keuangan dalam kasus tindak pidana korupsi. Lex Crimen, 2(2), 172-181.

Rini, R., \& Damiati, L. (2017). Analisis asil audit pemerintahan dan tingkat korupsi pemerintahan provinsi di Indonesia. Jurnal Dinamika Akuntansi Dan Bisnis, 4(1), 73-90. https://doi.org/10.24815/jdab.v4i1.4933

Rini, R., \& Sarah, A. (2014). Opini audit danpengungkapan atas laporan keuangan pemerintah kabupaten serta 
kaitannya dengan korupsi di Indonesia. Etikonomi, 13(1), 1-20.

Setyaningrum, D., Wardhani, R., \& Syakhroza, A. (2017). Good public governance, corruption and public service quality: Indonesia evidence. International Journal of Applied Business and Economic Research, 15(19), 327-338.

Sommaliagustina, D. (2019). Implementasi otonomi daerah dan korupsi kepala daerah. Journal of Governance Innovation, 1(1), 44-58. https://doi.org/10.36636/jogiv.v1i1.290

Tuanakotta, T. M. (2010). Akuntansi Forensik dan Audit Investigatif(2nd ed.). Salemba Empat.

Umar, H. (2012). Pengawasan untuk pemberantasan korupsi. Jurnal Akuntansi Dan Auditing, 8(2), 109-122. 